\title{
ЕКОНОМІКА
}

УДК 330.341.1(477+438):005.342

DOI: https://doi.org/10.26642/jen-2020-4(94)-3-10

Н.А. Мазур, д.е.н., проф.

Кам'янець-Подільський національний університет ім. Івана Огієнка

Н.М. Суліма, к.е.н., доц.

Національний університет біоресурсів і природокористування Украӥни

\section{Інноваційна діяльність в Україні та Польщі: стан, особливості та перспективи}

Обтрунтовано на основі порівняльного аналізу стан та особливості провадження інноваційної діяльності в Украӥні та Польщі, спільні й відмінні риси такої діяльності, а також окреслено можливі перспективи підвищення ефективності та подальшого розвитку реалізащії інноваційних процесів. Проведені дослідження засвідчують особливості та суттєву різницю в окремих показниках інноваційної діяльності підприємств досліджуваних краӥн. Зокрема, у 2016 2018 роках частка інновачійно активних підприємств у секторі промислових підприємств Польщі становила 26,1 \%, а у сфері послуг - 21,0\%. В Україні частка інновачійно активних підприємств у секторі промислових підприємств з 2010 до 2018 року зросла на 2,6\%, проте за період 2016-2018 років зменшилася з 18,9 до 16,4% загальної кількості промислових підприємств. Упродовж 2018 року наукові дослідження $і$ розробки в Україні виконувало 950 організацій (найменша кількість за період 2010-2018 років), 48,1\% з яких належали до державного сектору економіки, 36,9 \% - до підприємницького та 14,9 \% - до вищої освіти.

Динаміка зміни внутрішніх витрат на виконання НДР у порівнюваних краӥнах засвідчу, щзо за останні три роки аналізований показник у Польщуі зріс майже на 43 \%, тоді як в Україніна 45,5 в. п. відповідно. А от порівняно з 2010 роком у Польщі обсяг внутрішніх витрат на виконання НДР збільшився майже у 2,5 раза, тоді як в Украӥні - у 2,1 раза. Таким чином, спостерігаємо прискорення протягом останніх років темпів зростання обсягів внутрішніх витрат на виконання НДР в Україні, щуо є певним позитивним фактором.

Мени оптимістичною є ситуація в Україні з часткою загального обсягу витрат у ВВП - за 2017 рік вона становила 0,45 в. п. Аналогічний показник у крайнах $6 C-28$ у середньому становив 2,06 в. п. (щео у 4,5 раза перевищує показник Украӥни).

Проведений аналіз дає можливість зробити висновки, щุо за умови збереження існуючих тенденцій у кількості виконавців та дослідників, залучених до інновачійної діяльності, наша краӥна матиме не дуже оптимістичні прогнози щзодо покращення інноваційної діяльності.

Ключові слова: інновачї; інноваційна діяльність; інноваційний продукт; наукові дослідження і розробки (НДР).

Актуальність теми. Конкурентоспроможність країни визначається їі здатністю максимально швидко генерувати та впроваджувати інновації. Крім того, знання про інноваційну діяльність є важливими у процесі формування стратегії підприємств. Підвищення креативності підприємств, їх залучення до досліджень та розробок або співпраці з іншими суб'єктами створюють нові, кращі та ефективніші рішення, що впливають на зростання конкурентоспроможності фізичних та юридичних осіб. Інновації $\epsilon$ основою стійкого економічного зростання країни та поліпшення іiі економічних і соціальних умов.

Аналіз останніх досліджень і публікацій. Питанням економічної сутності інноваційної діяльності підприємств та інноваційних процесів присвятили свої роботи такі вчені, як: О.Г. Шпикуляк, С.Ілляшенко, Т.П. Близнюк, О.В. Чумак, Р.А. Фатхутдінов, О.М. Файчук, В.М. Мішина, І.А. Шейко, О.П. Коюда та багато інших [1].

Для можливого аналізу та порівняння інноваційної діяльності України та сусідньої Польщі розглянемо насамперед підходи, критерії та визначення інноваційної діяльності за нормативними та регулюючими документами обох країн. Так Закон України «Про інноваційну діяльність» визначає інноваційну діяльність як таку, «що спрямована на використання і комерціалізацію результатів наукових досліджень та розробок і зумовлює випуск на ринок нових конкурентоздатних товарів і послуг» [2]. Під інноваційною діяльністю розуміють усі наукові, технологічні, організаційні, фінансові та комерційні дії, що реально призводять до здійснення інновацій або задумані з цією метою. До такої діяльності також належать дослідження і розробки, не пов'язані прямо з підготовкою конкретної інновації.

Законодавче поле Польщі трактує інновації як «послідовність заходів, що ведуть до створення нових або вдосконалених продуктів або бізнес-процесів». Це може виникнути як в результаті досліджень і розробок, так і внаслідок появи попиту на нові та вдосконалені продукти [3].

Під впровадженням інновацій розуміють введення у вжиток будь-якого нового або значно вдосконаленого продукту (товару, послуги) або процесу, нового методу маркетингу чи нового організаційного методу в діяльності підприємства, організації робочих місць або зовнішніх зв'язків. 
Інновація є новою для ринку, коли підприємство, яким вона впроваджена, першим виводить їі на свій ринок. Мінімальний рівень новизни для зарахування будь-якої зміни до категорії «інновація» визначають як нове для підприємства. Продукт уже можна використовувати (виготовляти) на інших підприємствах, але якщо він є новим або істотно поліпшеним для цього підприємства, то така зміна розглядається для нього як інновація.

Під інноваційною продукцією (товарами, послугами) розуміємо продукцію (товари, послуги), яка $є$ новою або значно вдосконаленою в частині пї властивостей або способів використання. Новими продуктами вважають товари та послуги, що суттєво відрізняються своїми характеристиками або призначенням від продуктів, що виготовлялися підприємством раніше. Значні покращення можуть бути здійснені за рахунок змін у матеріалах, компонентах та інших характеристиках виробів, що покращують їхні властивості. Сюди зараховують значні вдосконалення у технічних характеристиках, компонентах і матеріалах, у вбудованому програмному забезпеченні та інших функціональних характеристиках.

Інноваційний продукт є результатом виконання інноваційного проєкту і науково-дослідною і (або) дослідно-конструкторською розробкою нової технології (в тому числі інформаційної) чи продукції 3 виготовленням експериментального зразка чи дослідної партії і відповідає таким вимогам:

а) він є реалізацією (впровадженням) об'єкта інтелектуальної власності (винаходу, корисної моделі, промислового зразка, топографії інтегральної мікросхеми, селекційного досягнення тощо), на які виробник продукту має державні охоронні документи (патенти, свідоцтва) чи одержані від власників цих об'єктів інтелектуальної власності ліцензії, або реалізацією (впровадженням) відкриттів. При цьому використаний об'єкт інтелектуальної власності має бути визначальним для цього продукту;

б) розробка продукту підвищує вітчизняний науково-технічний і технологічний рівень;

в) в Україні цей продукт вироблено (буде вироблено) вперше, або якщо не вперше, то порівняно 3 іншим аналогічним продуктом, представленим на ринку, він $є$ конкурентоздатним і має суттєво вищі техніко-економічні показники [2].

Метою дослідження є аналіз стану та особливостей провадження інноваційної діяльності в Україні та Польщі, спільних і відмінних рис такої діяльності, а також окреслення можливих перспектив підвищення ефективності та подальшого розвитку реалізації інноваційних процесів.

Викладення основного матеріалу. Для інноваційних підприємств Польщі саме підприємство має найбільше значення серед джерел інформації для інновацій. Для 47 \% підприємств у Польщі зазначене джерело інформації оцінюється високо, і цей результат є трохи нижчим середнього рівня в ЄС (49 \%). Постачальники вказані на другому місці, і цей результат нижче середнього показника по ЄС, що становить 27 \%. На третьому місці серед джерел інформації для інновацій - покупці або споживачі. Отримання знань від нинішніх чи потенційних покупців продукції є дуже важливим 3 точки зору стратегії збуту інноваційної продукції. Наступними потенційними джерелами інформації про інновації, зазначеними польськими компаніями, були діяльність конкурентних підприємств, а потім інформація наукових установ, університетів та науково-дослідних центрів [3].

В Україні під інноваційним підприємством (інноваційним центром, технопарком, технополісом, інноваційним бізнес-інкубатором тощо) розуміють підприємство (об'єднання підприємств), що розробляє, виробляє і реалізує інноваційні продукти і (або) продукцію чи послуги, обсяг яких у грошовому вимірі перевищує 70 \% його загального обсягу продукції і (або) послуг [2]. Упродовж 2018 року наукові дослідження і розробки в Україні виконували 950 організацій (найменша кількість за період 2010-2018 років), 48,1 \% (або 457 од.) 3 яких належали до державного сектору економіки, 36,9 \% (351 од.) - до підприємницького, 14,9 \% (142 од.) - до вищої освіти. Рівень фінансування наукових досліджень і розробок у загальному обсязі витрат в Україні, Польщі та ЄС наведено у таблиці 1.

Таблиия 1

Частка фінансування витрат на виконання НДР у загальному обсязі витрат, \%

\begin{tabular}{|c|c|c|c|}
\hline Сектор & Україна & Польща & CС-28 \\
\hline 1 & 2 & 3 & 4 \\
\hline Підприємницький сектор & & & 53,8 \\
\hline 2010 & 23,8 & 24,4 & 55,3 \\
\hline 2015 & 39,6 & 39,0 & 56,6 \\
\hline 2016 & 36,9 & 53,1 & $\ldots$ \\
\hline 2018 & 31,4 & 53,3 & 34,8 \\
\hline Державний сектор & & & 31,3 \\
\hline 2010 & 49,5 & 60,9 & 30,9 \\
\hline 2015 & 40,1 & 41,8 & $\ldots$ \\
\hline
\end{tabular}




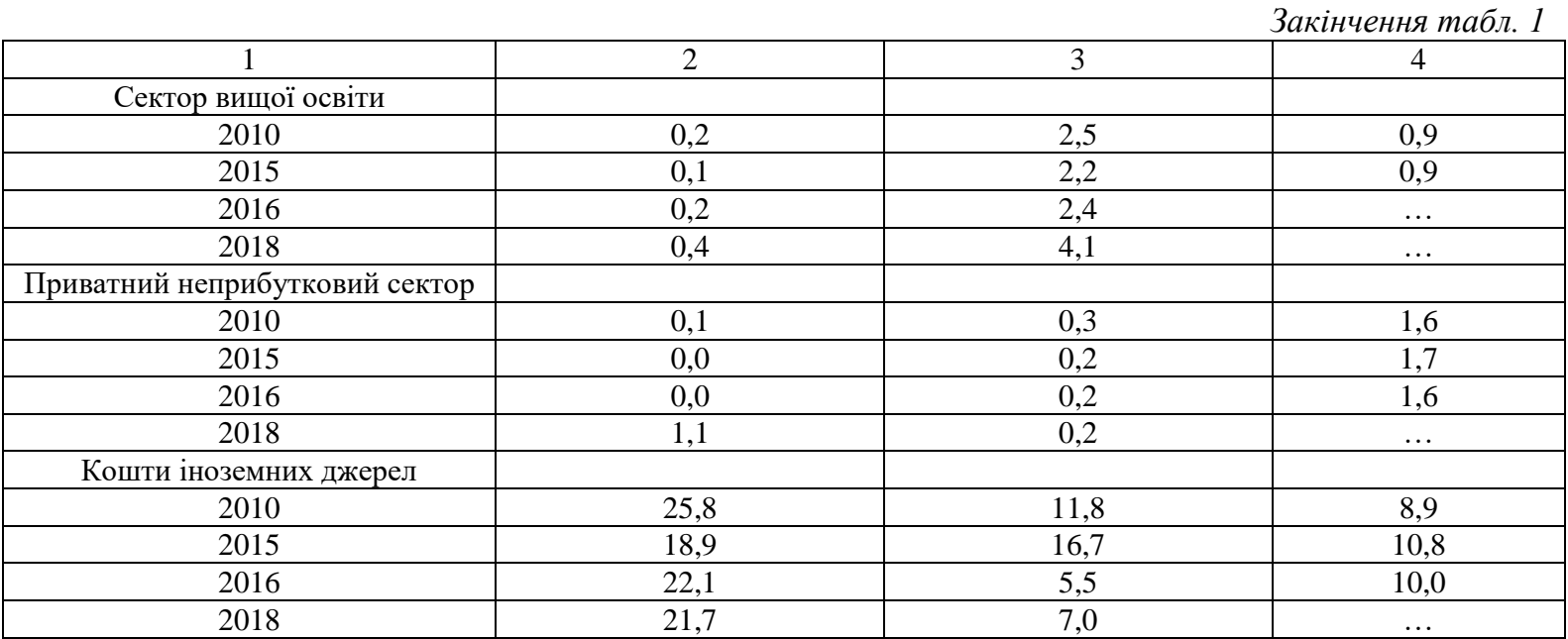

Джерело: розрахунки авторів за даними [4-7]

За 2018 рік загальний обсяг витрат на виконання НДР власними силами організацій України становив 16773,7 млн грн, у тому числі витрати на оплату праці - 8553,0 млн грн, інші поточні витрати 7456,2 млн грн, капітальні витрати - 764,4 млн грн, 3 них витрати на придбання устаткування 588 млн грн. Динаміку зміни внутрішніх витрат на виконання НДР у порівнюваних країнах (Україні та Польщі) наведено на рисунку 1. При цьому необхідно зазначити, що за останні три роки аналізований показник у Польщі зріс майже на 43 \%, тоді як в Україні - на 45,5 в. п. відповідно. А от порівняно з 2010 роком у Польщі обсяг внутрішніх витрат на виконання НДР збільшився майже у 2,5 раза, тоді як в Україні - у 2,1 раза.

Таким чином, можемо зробити висновок про прискорення протягом останніх років темпів зростання обсягів внутрішніх витрат на виконання НДР в Україні, що є певним позитивним фактором.

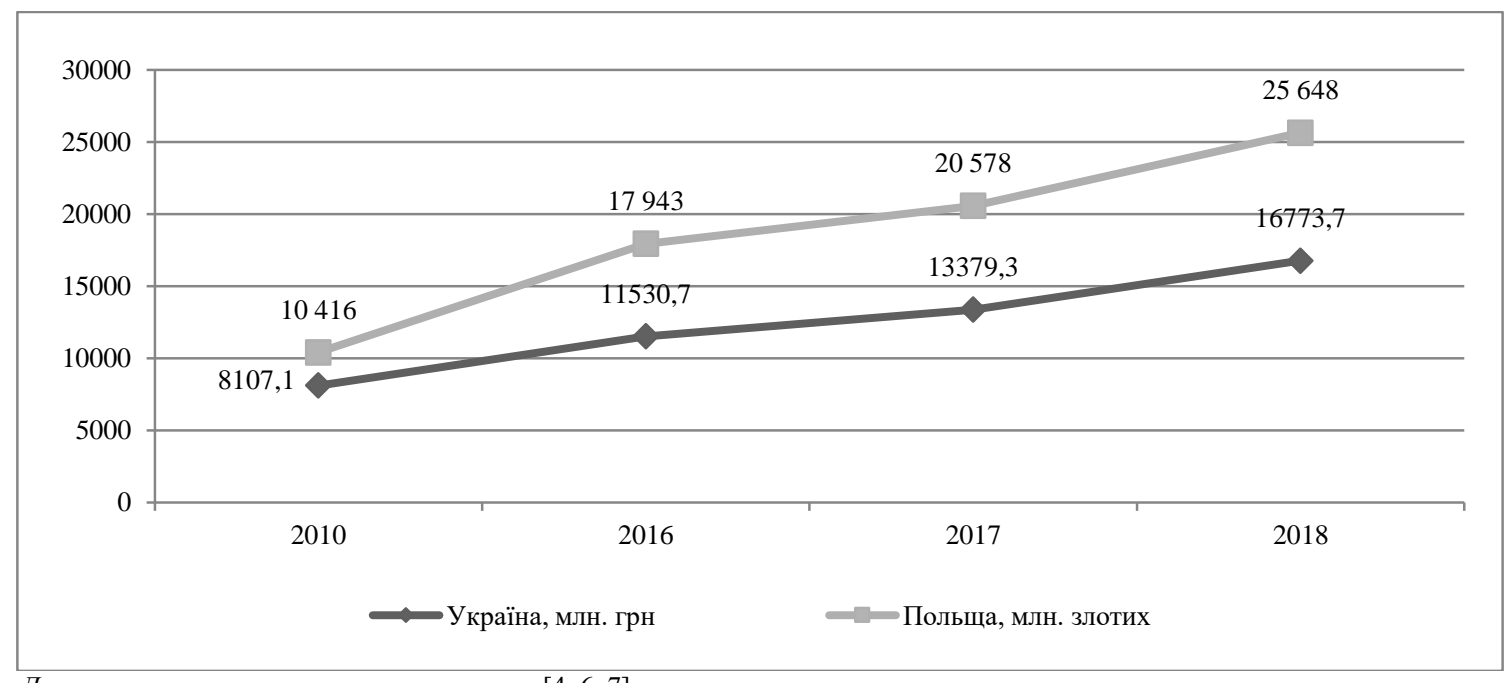

Джерело: розраховано авторами за даними $[4,6,7]$

Рис. 1. Внутрішні витрати на виконання НДР у динаміияі

Менш оптимістичною є ситуація в Україні з часткою загального обсягу витрат у ВВП - за 2017 рік вона становила 0,45 в. п. Аналогічний показник у країнах ЄС-28 у середньому становив 2,06 \% (що у 4,5 раза перевищує показник України) - рисунок 2. Більшою за середню частка витрат на дослідження та розробки була у Швеції (3,25 \%), Австрії (3,09\%), Німеччині (2,94 \%), Данії (2,87 \%), Фінляндії (2,75 \%), Бельгії (2,49 \%); меншою - у Македонії, Латвії, Румунії, Кіпру та Мальти (від 0,43 до 0,61 \%) [4].

У 2017 році 22,4 \% загального обсягу витрат в Україні були спрямовані на виконання фундаментальних наукових досліджень, які на 86,9 \% профінансовано за рахунок коштів бюджету. Частка витрат на виконання прикладних наукових досліджень становила 21,3%, які на 57,5 \% фінансувалися за рахунок коштів бюджету та на $27,2 \%$ - за рахунок коштів організацій підприємницького сектору. На виконання науково-технічних (експериментальних) розробок спрямовано 56,3 \% загального обсягу витрат. Майже половина обсягу витрат, направленого на виконання 
фундаментальних наукових досліджень, припадала на галузь природничих наук (48,4 \%), 24,8 \% технічних, 8,7 \% - сільськогосподарських. На виконання прикладних наукових досліджень спрямовано $37,8 \%$ витрат галузі технічних наук, 23,2 \% - природничих, по 12,9 \% - медичних та сільськогосподарських. Переважна частина (88,9 \%) витрат на виконання науково-технічних (експериментальних) розробок припадає на галузь технічних наук [4].

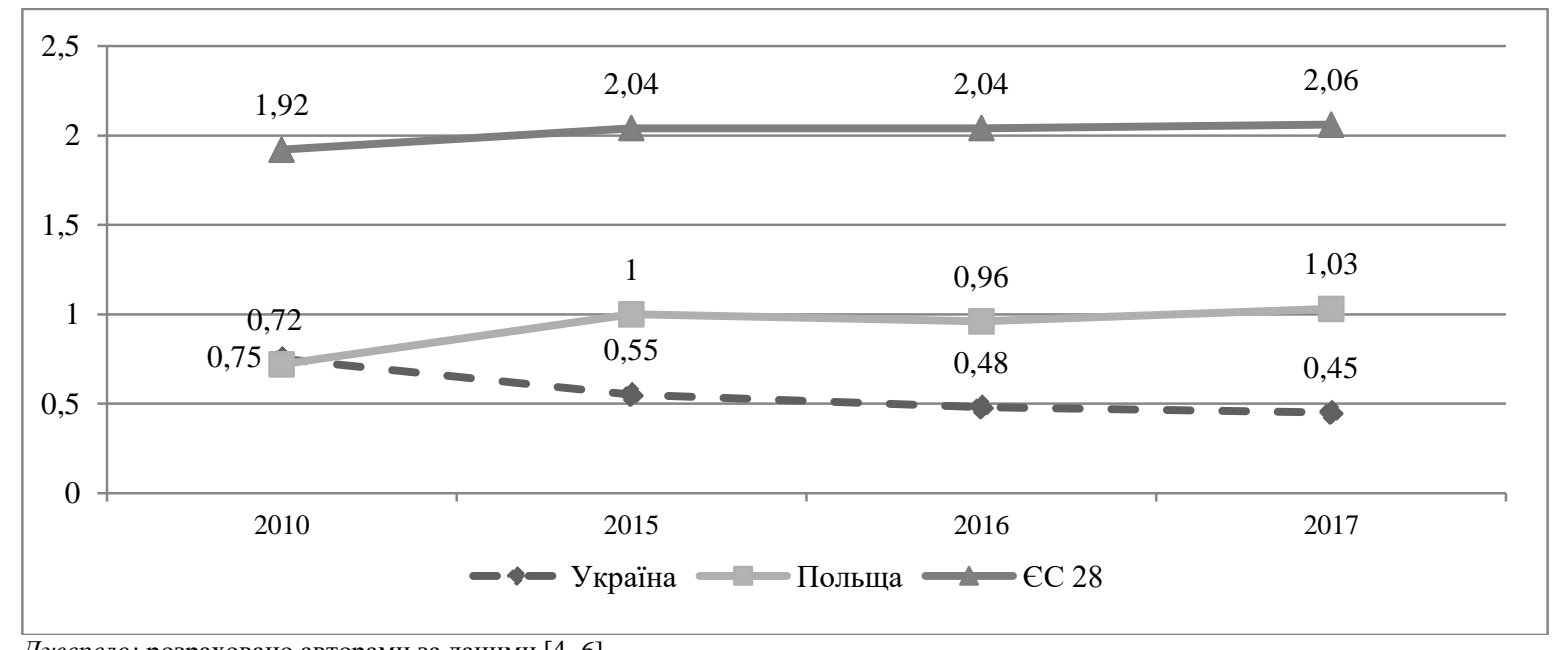

Дюжерело: розраховано авторами за даними [4-6]

Рис. 2. Питома вага витрат на виконання НДР у ВВП у динаміці, \%

У Польщі в 2016-2018 роках продуктові інновації реалізували 16,8 \% промислових підприємств та 9,6 \% підприємств, що надають послуги. Найвищий відсоток підприємств промисловості та послуг, які у 2016-2018 роках запровадили продуктові інновації, був зафіксовано у суб'єктів, 3 кількістю працівників 250 осіб і більше (відповідно 48,0 \% та 26,3 \% юридичних осіб). В Україні за аналогічний період продуктові інновації реалізувало лише 4 \% загальної кількості промислових підприємств. Відсоток підприємств промисловості, які у 2016-2018 роках запровадили продуктові інновації, де працювало 250 осіб і більше, становив 15,9 \% від кількості інноваційно активних підприємств.

У 2016-2018 роках інновації бізнес-процесів реалізовували 19,9 \% промислових підприємств та 17,5 \% підприємств сфери послуг. Найвищий відсоток підприємств промисловості та послуг, що запровадили за цей період інновації у бізнес-процесах, зафіксовано у суб'єктів, з кількістю працівників 250 осіб і більше (56,9 \% та 44,1 \% суб’єктів відповідно). В Україні за аналогічний період процесові інновації реалізували лише 4,7 \% загальної кількості промислових підприємств. Відсоток підприємств промисловості, які у 2016-2018 роках запровадили процесові інновації та на яких працювало 250 осіб і більше, становив 21,3 \% від кількості інноваційно активних підприємств.

Наступним етапом аналізу є порівняння України та Польщі за кількістю виконавців та дослідників, що були залучені до інноваційної діяльності (табл. 2). Так на підприємствах та в організаціях України, які здійснювали НДР, кількість виконавців таких робіт на кінець 2018 року становила 88128 осіб (з урахуванням сумісників та осіб, які працюють за договорами цивільно-правового характеру), що на $52 \%$ менше порівняно з кількістю працівників у 2010 році. 3 них 65,4 \% - дослідники, 9,7 \% - техніки, 24,9 \% допоміжний персонал. У 2018 році частка виконавців НДР (дослідників, техніків і допоміжного персоналу) у загальній кількості зайнятого населення становила 0,54 \%, у тому числі дослідників - 0,35 \% [4].

Таблиия 2

Кількість виконавців НДР та дослідників у розрахунку на 1000 осіб зайнятого населення*, \%

\begin{tabular}{|c|c|c|c|c|c|c|c|c|c|c|c|c|}
\hline \multirow[b]{2}{*}{ Країна } & \multicolumn{6}{|c|}{ Виконавці наукових досліджень і розробок } & \multicolumn{6}{|c|}{ Дослідники } \\
\hline & 2010 & 2015 & 2016 & 2017 & 2018 & $\begin{array}{c}\text { зміна, } \\
+/-\end{array}$ & 2010 & 2015 & 2016 & 2017 & 2018 & $\begin{array}{c}\text { зміна, } \\
+/-\end{array}$ \\
\hline Україна & 9,5 & 7,5 & 6,0 & 5,8 & 5,4 & $-4,1$ & 7,0 & 5,5 & 3,9 & 3,7 & 3,5 & $-3,5$ \\
\hline Польща & 8,5 & 10,0 & 10,8 & 14,6 & 16,1 & $+7,6$ & 6,6 & 7,5 & 8,3 & 9,2 & 9,2 & $+2,6$ \\
\hline $\mathrm{EC}-28 * *$ & 17,9 & 20,4 & $\ldots$ & 27,7 & 28,5 & $+10,6$ & 11,5 & 13,3 & & 18,0 & 18,6 & $+7,1$ \\
\hline
\end{tabular}

Джерело: розраховано авторами за даними $[4,5]$.

Примітка: *у віці 15-70 років - для України, 15 і більше - для інших;

**до 1 липня 2013 року - ЄС-27 
Наведені дані яскраво засвідчують суттєву різницю між кількістю виконавців наукових досліджень і розробок та дослідників починаючи з 2016 року. Так в Україні чисельність виконавців за 2016-2018 роки зменшилася 3 6,0 до 5,4 \%, тоді як у Польщі показник зріс з 10,8 до 16,1%. При цьому за 2018 рік чисельність виконавців наукових досліджень і розробок у Польщі більше, ніж у 3 рази перевищувала показник України, а показник ЄС-28 перевищував український більше, ніж у 5 разів.

Аналіз динаміки кількості дослідників засвідчує майже аналогічну ситуацію та дає можливість зробити висновки, що за умови збереження існуючих тенденцій у кількості виконавців та дослідників, залучених до інноваційної діяльності, наша країна матиме не дуже оптимістичні прогнози щодо покращення такої діяльності.

Місце інноваційної інфраструктури в системі забезпечення процесу створення нової техніки i технології (ПСНТ) показано на рисунку 3. Зважаючи на зміст етапів ПСНТ крім інноваційної інфраструктури доцільно виокремити інноваційно-виробничу, яка охоплює етап процесу виробництва інноваційної продукції, та інфраструктуру ринку інновацій, яка забезпечує процеси комерційної реалізації інноваційної продукції та дифузію інновацій.

\begin{tabular}{|c|c|c|c|c|c|}
\hline \multicolumn{4}{|c|}{ Процес створення нової техніки і технологій ПСНТТ } & \multicolumn{2}{|c|}{$\begin{array}{l}\text { Процес комерційної реалізації } \\
\text { інноваційної продукції ПКРІП }\end{array}$} \\
\hline $\begin{array}{c}\text { Фундаментальні } \\
\text { дослідження } \\
\text { ФД }\end{array}$ & $\begin{array}{c}\text { Прикладні } \\
\text { дослідження } \\
\text { ПД }\end{array}$ & $\begin{array}{c}\text { Дослідно- } \\
\text { конструкторські } \\
\text { роботи ДКР }\end{array}$ & $\begin{array}{c}\text { Промислове } \\
\text { виробництво } \\
\text { інноваційної } \\
\text { продукції ПВ } \\
\end{array}$ & $\begin{array}{c}\text { Комерційна реалізація } \\
\text { інноваційної } \\
\text { Продукції КР }\end{array}$ & $\begin{array}{c}\text { Дифузія } \\
\text { інновацій } \\
\text { ДІ }\end{array}$ \\
\hline \multicolumn{6}{|c|}{$\begin{array}{c}\text { Сфера обслуговування об’єктами інноваційної } \\
\text { інфраструктури }\end{array}$} \\
\hline \multicolumn{4}{|c|}{ Сфера обслуговування об’єктами інноваційно-виробничої інфраструктури } & \multicolumn{2}{|c|}{$\begin{array}{l}\text { Сфера обслуговування об’єктами } \\
\text { інфраструктури ринку інновацій }\end{array}$} \\
\hline
\end{tabular}

Джерело: розроблено авторами

\section{Рис. 3. Спрямованість інфраструктури залежно від охоплення етапів процесу створення} і комерціалізащії інноваційної продукціі

Під інноваційною інфраструктурою розуміємо увесь спектр структур як державної, так і приватної форм власності, що необхідні для забезпечення розвитку та підтримки всіх стадій інноваційного процесу. За теорією нерівномірності інноваційної діяльності для активізації такої діяльності кожного окремого підприємства необхідна наявність відповідних складових інноваційної діяльності як на рівні підприємства, так і економіки в цілому [8].

Оскільки інновація є результатом науково-технічного прогресу, не варто плутати суто наукові та комерційно-прикладні інноваційні пріоритети, адже вимоги до інфраструктур у першому та другому випадках не є ідентичними. Обгрунтування цієї тези вимагає такого розуміння класифікації науковотехнічного прогресу: науково-технічний прогрес доцільно розділити умовно на два взаємопов'язані і взаємодоповнюючі сегменти - сегмент науково-технологічних досягнень і сегмент виробничогосподарських досягнень.

У першому випадку метою та результатами науково-технічного прогресу є наукові досягнення, такі як певні набуті нові знання і вміння, нові науково-технічні ідеї та їх обгрунтування, винаходи, відкриття, нові технології на кардинально нових принципах. У другому ж випадку і метою, і результатами науковотехнічного прогресу є виробничо-технологічні досягнення.

Iз зазначеного можна зробити висновок, що під інноваційною діяльністю в іiі практичному, виробничо-господарському баченні потрібно розуміти діяльність окремих осіб чи організацій, спрямовану на реалізацію із комерційною метою деяких виробничо-господарських досягнень, застосування прогресивних технологій, систем, обладнання і машин на базі впровадження науковотехнологічних досягнень. Ефективність провадження такої практично спрямованої інноваційної діяльності багато в чому визначається інноваційною інфраструктурою. Тому інноваційна інфраструктура $\epsilon$ базовою складовою інноваційної економіки, інноваційного потенціалу суспільства, фундаментом інноваційного процесу.

Достатньо розвинена інноваційна інфраструктура зумовлює темпи розвитку економіки країни $\mathrm{i}$ зростання добробуту іiі населення. Досвід розвинених країн світу свідчить, що в умовах глобальної конкуренції на світовому ринку неминуче виграє той, хто має розвинену інфраструктуру створення і реалізації інновацій, хто володіє найефективнішим механізмом інноваційної діяльності.

У нинішніх умовах економіки необхідно забезпечити ефективний взаємозв'язок науково-технічного потенціалу науково-навчальних установ, інноваційних структур і безпосередньо товаровиробників, що функціонують відокремлено. Складові інноваційної інфраструктури мають тісно взаємодіяти із товаровиробниками з метою отримання зворотного зв'язку науки і виробництва, стимулюючи наукові установи здійснювати інноваційні розробки з високою практичною значущістю. 
Проаналізуємо основні показники інноваційно активних підприємств (підприємств, які займалися інноваційною діяльністю) у таблиці 3.

Таблиця 3

Основні показники інноваційної діяльності промислових підприємств

\begin{tabular}{|c|c|c|c|c|c|c|c|c|c|c|}
\hline \multirow[b]{2}{*}{ Показник } & \multicolumn{5}{|c|}{ Україна } & \multicolumn{5}{|c|}{ Польща } \\
\hline & 2010 & 2016 & 2017 & 2018 & $\begin{array}{l}\text { зміна, } \\
+/-\end{array}$ & 2010 & 2016 & 2017 & 2018 & $\begin{array}{c}\text { зміна, } \\
+/-\end{array}$ \\
\hline $\begin{array}{l}\text { Кількість інноваційно } \\
\text { активних промислових } \\
\text { підприємств, } \\
\text { \% до загальної } \\
\text { кількості промислових } \\
\text { підприємств }\end{array}$ & 13,8 & 18,9 & 16,2 & 16,4 & $+2,6$ & 18,1 & 20,3 & 20,2 & 26,1 & $+8,0$ \\
\hline $\begin{array}{l}\text { Витрати на інновації, } \\
\text { млн грн / злт }\end{array}$ & 8045,5 & 23229,5 & 9117,5 & 12180,1 & $+4134,6$ & 23757,8 & 28304,7 & 28023,5 & 23388,7 & $-369,1$ \\
\hline
\end{tabular}

Джерело: розраховано авторами за даними $[4,6,7]$

У 2016-2018 роках частка інноваційно активних підприємств у секторі промислових підприємств Польщі становила 26,1 \%, а у сфері послуг - 21,0%. Враховуючи класи підприємств за величиною, найбільший відсоток інноваційно активних суб'єктів (як промислових, так і сфери послуг) є характерним для таких, де працюють 250 осіб і більше.

В Україні частка інноваційно активних підприємств у секторі промислових підприємств з 2010 по 2018 роки зросла на 2,6 \%, проте за період 2016-2018 років зменшилася - 3 18,9 до 16,4 \% загальної кількості промислових підприємств.

У промисловій переробці Польщі найбільший відсоток інноваційно активних підприємств зафіксовано у розділі «Виробництво фармацевтичної продукції» $(58,4$ \%). Що стосується підприємств, які надають послуги, цей коефіцієнт був найвищим за видом діяльності «Наукові дослідження та розробки» (80,2 \%). Найменшу інноваційну активність у промисловій переробці продемонстрували компанії, що виробляють одяг (13,3\%), а в послугах - наземний трубопровідний транспорт $(13,4 \%)$.

Чим вищий рівень прогресу технологій, тим більший відсоток підприємств, що впроваджують інновації. Так у Польщі частка інноваційних підприємств промислової переробки за 2016-2018 роки, які класифіковані як такі, що мають високі технології, була майже втричі вищою, ніж у підприємств 3 низькою технологією.

Обов'язковим етапом аналізу інноваційної діяльності підприємств є аналіз витрат. Внутрішні витрати на виконання наукових досліджень і розробок (фінансові витрати на інноваційну діяльність у сфері інновацій продукції і бізнес-процесів) - це загальна сума витрат на виконання наукових досліджень і розробок власними силами організації. До витрат належать внутрішні поточні витрати (витрати на оплату праці, матеріальні витрати та інші поточні витрати) та капітальні вкладення (витрати на основні засоби, пов'язані 3 виконанням наукових досліджень і розробок установи, за винятком суми амортизаційних відрахувань на повне відновлення основних засобів).

Як свідчать дані таблиці 3, у 2018 році витрати на інноваційну діяльність у групі промислових підприємств Польщі становили 23,4 млрд злотих, що на 16,5 \% менше, ніж у 2017 році, тоді як у групі підприємств сфери послуг (як і в попередньому році) - 13,1 млрд злотих. Як і в попередні роки найвищі витрати на інноваційну діяльність серед підприємств промисловості та сфери послуг здійснювали суб'єкти 3 кількістю працівників 250 осіб і більше. Їх частка у витратах на інновації підприємств в цілому була дуже високою (у промисловості вона становила 75,1 \%, у сфері послуг - 69,5 \%), але за останній аналізований рік вона зменшилася (на 3,9 та 4,1 в. п. відповідно).

В Україні за 2018 рік промислові підприємства витратили на інноваційну діяльність 12,2 млрд грн, що на 3,1 млрд (або на 33,5 \%) більше порівняно з попереднім 2017 роком. Необхідно обов'язково зазначити, що найбільшим обсяг витрат на виконання наукових досліджень і розробок був у 2016 році 23,2 млрд грн.

Так саме у 2016 році була найбільшою кількість впроваджених видів інноваційної продукції (товарів, послуг) - 4139 од., 3 яких 1305 - нові види машин, устаткування, приладів, апаратів. Також найвищим був показник впроваджених у виробництво нових технологічних процесів - 3489, з яких 748 нових або суттєво поліпшених маловідходних, ресурсозберігаючих.

У доповіді «Глобальний індекс інновацій 2019» наведено дані про інноваційну діяльність 129 країн і територій світу (за 80 параметрами, які використовуються для оцінки, дають повну картину інноваційного розвитку). За цим рейтингом Польща у 2018 та 2019 роках займала 39 позицію, а Україна у 2019 році втратила в рейтингу 4 позиції й посіла 47 місце [9].

Але як зазначалося на початку статті, здатність максимально швидко генерувати та впроваджувати інновації визначає конкурентоспроможність країни. Відтак за даними звіту Світового економічного 
форуму щодо глобальної конкурентоспроможності «The Global Competitiveness Report 2019» Україна займає 85 позицію в рейтингу серед 141 досліджуваної країни (із втратою 2 позицій за рік). При цьому Польща зайняла 37 місце (як і у 2018 році) [10].

Висновки. Таким чином, проведені дослідження засвідчують особливості та суттєву різницю в окремих показниках інноваційної діяльності підприємств досліджуваних країн. Зокрема, у 20162018 роках частка інноваційно активних підприємств у секторі промислових підприємств Польщі становила 26,1 \%, а у сфері послуг - 21,0 \%. В Україні частка інноваційно активних підприємств у секторі промислових підприємств з 2010 до 2018 року зросла на 2,6 \%, проте за період 2016-2018 років зменшилася - 3 18,9 до 16,4 \% загальної кількості промислових підприємств.

Динаміка зміни внутрішніх витрат на виконання НДР у порівнюваних країнах засвідчує, що за останні три роки аналізований показник у Польщі зріс майже на 43 \%, тоді як в Україні - на 45,5 в. п. відповідно. А от порівняно 32010 роком у Польщі обсяг внутрішніх витрат на виконання НДР збільшився майже у 2,5 раза, тоді як в Україні - у 2,1 раза. Отже, можемо зробити висновок про прискорення протягом останніх років темпів зростання обсягів внутрішніх витрат на виконання НДР в Україні, що є певним позитивним фактором.

Менш оптимістичною є ситуація в Україні з часткою загального обсягу витрат у ВВП - за 2017 рік вона становила 0,45 в. п. Аналогічний показник у країнах ЄС-28 у середньому становив 2,06\% (що у 4,5 раза перевищує показник України).

Проведений аналіз дає можливість зробити висновки, що за умови збереження існуючих тенденцій у кількості виконавців та дослідників, залучених до інноваційної діяльності, наша країна матиме не дуже оптимістичні прогнози щодо покращення такої діяльності.

Для підвищення ефективності та подальшого розвитку реалізації інноваційних процесів необхідними є доступність і достовірність інформації; достатність фінансових ресурсів; якісна та об'єктивна науковотехнічна експертиза; захист об'єктів інтелектуальної власності; поширення інформації та досвіду ефекту нововведень; організація навчання та консультування кадрів, а також вирішення багатьох інших питань, що забезпечує інноваційна інфраструктура.

\section{Список використаної літератури:}

1. Полозова Т.В. Інноваційна діяльність підприємства та економічна сутність інноваційного процесу / Т.В. Полозова, Д.Ю. Кривиун // Науковий вісник Міжнародного гуманітарного університету. - 2015. № 12. - С. 108-113 [Електронний pecypc]. - Режим доступу : http://www.vestnikeconom.mgu.od.ua/journal/2015/12-2015/26.pdf.

2. Про інноваційну діяльність : Закон України № 40-IV від 04.07.2002 ; поточна редакція від 05.12.2012 [Електронний ресурс]. - Режим доступу : https://zakon.rada.gov.ua/laws/show/40-15/ed20121205\#Text.

3. Innowacyjność przedsiębiorstw // eRegion [Electronic resource]. - Access mode http://eregion.wzp.pl/obszary/innowacyjnosc-przedsiebiorstw.

4. Офіційний сайт Державної служби статистики України [Електронний ресурс]. - Режим доступу : http://ukrstat.gov.ua.

5. Eurostat [Electronic resource]. - Access mode : https://ec.europa.eu/eurostat

6. Mały Rocznik Statystyczny Polski (Concise Statistical Yearbook of Poland). - Warszawa : Główny Urząd Statystyczny, 2018 [Electronic resource]. - Access mode : https://stat.gov.pl/files/gfx/portalinformacyjny/pl/defaultaktualnosci/5515/1/19/1/maly_rocznik_statystyczny_polsk i_2018.pdf.

7. Działalność innowacyjna przedsiębiorstw w latach 2016-2018. - Warszawa ; Szczecin : Główny Urząd Statystyczny ; Urząd Statystyczny w Szczecinie, 2019 [Electronic resource]. - Access mode : http://eregion.wzp.pl/sites/default/files/dzialalnosc_innowacyjna_przedsiebiorstw_w_latach_2016-2018.pdf.

8. Інноваційний розвиток підприємства : навчальний посібник / П.П. Микитюк, Ж.Л. Крисько, О.Ф. ОвсянюкБердадіна, С.М. Скочиляс. - Тернопіль : ПП «Принтер Інформ», 2015. - 224 с.

9. Інноваційна діяльність в Україні у 2019 році : науково-аналітична доповідь / T.В. Писаренко, Т.К. Квама, Л.В. Рожкова, О.В. Коваленко. - К. : УкрIНТЕІ, 2020. - 45 с.

10. The Global Competitiveness Report 2019 / ed. by Klaus Schwab. - World Economic Forum [Electronic resource]. - Access mode : http://www3.weforum.org/docs/WEF_TheGlobalCompetitivenessReport2019.pdf.

\section{References:}

1. Polozova, T.V. and Kryvcun, D.Ju. (2015), «Innovacijna dijal'nist' pidpryjemstva ta ekonomichna sutnist' innovacijnogo procesu», Naukovyj visnyk Mizhnarodnogo gumanitarnogo universytetu, No. 12, pp. 108-113, [Online], available at: http://www.vestnik-econom.mgu.od.ua/journal/2015/12-2015/26.pdf

2. Zakon Ukrai'ny No. 40-IV Pro innovacijnu dijal'nist', vid 04.07.2002, potochna redakcija vid 05.12.2012, [Online], available at: https://zakon.rada.gov.ua/laws/show/40-15/ed20121205\#Text

3. «Innowacyjność przedsiębiorstw», eRegion, [Online], available at: http://eregion.wzp.pl/obszary/innowacyjnoscprzedsiebiorstw

4. Oficijnyj sajt Derzhavnoi' sluzhby statystyky Ukrai'ny, [Online], available at: http://ukrstat.gov.ua 
5. Eurostat, [Online], available at: https://ec.europa.eu/eurostat

6. Mały Rocznik Statystyczny Polski (Concise Statistical Yearbook of Poland) (2018), Główny Urząd Statystyczny, Warszawa, [Online], available at: https://stat.gov.pl/files/gfx/portalinformacyjny/pl/defaultaktualnosci/5515/1/19/1/ maly_rocznik_statystyczny_polski_2018.pdf

7. Działalność innowacyjna przedsiębiorstw w latach 2016-2018 (2019), Główny Urząd Statystyczny, Urząd Statystyczny w Szczecinie, Warszawa, Szczecin, [Online], available at: http://eregion.wzp.pl/sites/default/files/dzialalnosc_innowacyjna_przedsiebiorstw_w_latach_2016-2018.pdf

8. Mykytjuk, P.P., Krys'ko, Zh.L., Ovsjanjuk-Berdadina, O.F. and Skochyljas, S.M. (2015), Innovacijnyj rozvytok pidpryjemstva, navchal'nyj posibnyk, PP «Prynter Inform», Ternopil', 224 p.

9. Pysarenko, T.V., Kvasha, T.K., Rozhkova, L.V. and Kovalenko, O.V. (2020), Innovacijna dijal'nist' v Ukrai'ni u 2019 roci, naukovo-analitychna dopovid', UkrINTEI, K., 45 p.

10. The Global Competitiveness Report 2019, in Schwab, Klaus (ed.), World Economic Forum, [Online], available at: http://www3.weforum.org/docs/WEF_TheGlobalCompetitivenessReport2019.pdf

Мазур Наталія Анатоліївна - доктор економічних наук, професор, завідувач кафедри економіки підприємства Кам'янець-Подільського національного університету імені Івана Огієнка.

https://orcid.org/0000-0002-4670-6805.

Наукові інтереси:

- формування системи і механізмів забезпечення конкурентоспроможного розвитку підприємств економіки України;

- облік, аналіз та оподаткування суб’єктів господарювання в управлінні підприємствами.

E-mail: natali76.01maz@gmail.com.

Суліма Наталія Миколаївна - кандидат економічних наук, доцент, доцент кафедри економіки підприємства ім. проф. І.Н. Романенка Національного університету біоресурсів і природокористування України.

https://orcid.org/0000-0002-3852-7989.

Наукові інтереси:

- економіка підприємств аграрного сектору.

E-mail:_s_n_@ukr.net. 